Article

\title{
Effectiveness of Aqueous Chlorine Dioxide in Minimizing Food Safety Risk Associated with Salmonella, E. coli O157:H7, and Listeria monocytogenes on Sweet Potatoes
}

\author{
Phillip Luu, Vijay Singh Chhetri ${ }^{\circledR}$, Marlene E. Janes, Joan M. King and Achyut Adhikari *(D) \\ School of Nutrition and Food Sciences, Louisiana State University Agricultural Center, Baton Rouge, LA 70803, \\ USA; pluu2@lsu.edu (P.L.); vijayschhetri@gmail.com (V.S.C.); MJanes@agcenter.lsu.edu (M.E.J.); \\ jking@agcenter.lsu.edu (J.M.K.) \\ * Correspondence: ACAdhikari@agcenter.lsu.edu; Tel.: +12-(25)-5782529
}

Received: 18 August 2020; Accepted: 5 September 2020; Published: 8 September 2020

check for updates

\begin{abstract}
Sodium hypochlorite $(\mathrm{NaOCl})$ is a commonly used sanitizer in the produce industry despite its limited effectiveness against contaminated human pathogens in fresh produce. Aqueous chlorine dioxide $\left(\mathrm{ClO}_{2}\right)$ is an alternative sanitizer offering a greater oxidizing potency with greater efficacy in reducing a large number of microorganisms. We investigated the effect of aqueous chlorine dioxide treatment against human pathogens, Salmonella, Escherichia coli O157:H7, and Listeria monocytogenes seeded on sweet potatoes. Sweet potatoes were spot inoculated (4.2 to $5.7 \mathrm{log} \mathrm{CFU} / \mathrm{cm}^{2}$ ) with multi-strain cocktails of Salmonella spp., E. coli O157:H7, and L. monocytogenes and treated for 10-30 min with 5 ppm aqueous $\mathrm{ClO}_{2}$ or water. Aqueous $\mathrm{ClO}_{2}$ treatment was significantly $(p<0.05)$ effective in reducing Salmonella with a reduction of $2.14 \log \mathrm{CFU} / \mathrm{cm}^{2}$ within $20 \mathrm{~min}$ compared to $1.44 \log \mathrm{CFU} / \mathrm{cm}^{2}$ for water treatment. Similar results were observed for L. monocytogenes with a $1.98 \log \mathrm{CFU} / \mathrm{cm}^{2}$ reduction compared to $0.49 \log \mathrm{CFU} / \mathrm{cm}^{2}$ reduction observed after $30 \mathrm{~min}$ treatment with aqueous $\mathrm{ClO}_{2}$ the water respectively. The maximum reduction in E. coli O157: $\mathrm{H} 7$ reached 2.1 $\mathrm{Log} C F U / \mathrm{cm}^{2}$ after $20 \mathrm{~min}$ of treatment with aqueous $\mathrm{ClO}_{2}$. The level of the pathogens in $\mathrm{ClO}_{2}$ wash solutions, after the treatment, was below the detectable limit. While in the water wash solutions, the pathogens' populations ranged from 3.47 to $4.63 \log$ CFU/mL. Our study indicates that aqueous $\mathrm{ClO}_{2}$ is highly effective in controlling cross-contamination during postharvest washing of sweet potatoes.
\end{abstract}

Keywords: chlorine dioxide; sweet potatoes; Salmonella; Escherichia coli O157:H7; Listeria monocytogenes

\section{Introduction}

Growing global populations have greatly increased the demand of wholesome fresh produce including sweet potatoes. The global sweet potato market has been on the rise since 2012, producing 105.2 million tons of the crop and yielding 1.4 million tons in 2016 in the United States alone [1]. Sweet potatoes are recognized as nutritiously potent crops consumed and researched globally [2,3]. The sweet potato is potentially an ideal and efficient crop for providing sustenance for much of the world as well as being a viable crop for sustainable agriculture [2,4]. The majority of sweet potatoes are produced by developing countries where the usage of raw manure as fertilizer is still common practice. In addition to pathogens found in raw manure, contaminated irrigation water and wildlife excrements pose potential threats to soil contamination.

Fresh produce commodities have been subject to numerous foodborne outbreaks in both the domestic and international markets [5]. With cross-contamination vectors including soil and irrigation 
water contamination as well as produce handling by field workers, postharvest sanitation is often the most vital step in reducing microbial contamination [6-8]. Fresh-cut produce sanitation has been well-researched. Few studies have highlighted the importance of postharvest sanitation of root crops. Root crops tend to be overlooked in favor of minimizing cross-contamination in fresh produce that are consumed raw. However, crops grown under the soil are vulnerable to harboring pathogens as a result of poor compost practices and the usage of contaminated irrigation water [9]. Despite cooking being an acceptable kill step in eliminating most pathogens, root crops such as sweet potatoes and potatoes that are typically cooked in sealed aluminum foil, an anaerobic environment, are susceptible to botulism as a result of $C$. botulinum spores germinating during the baking process [10,11]. Additionally, root vegetables such as carrots, beets, radishes, and sweet potatoes may also be eaten raw, which may pose a food safety risk.

Produce are washed to remove excess dirt and debris from surfaces. However, without a sanitizing agent in the wash solution, washing will have minimal impact on reducing bacterial populations [12,13]. Sweet potatoes are sanitized in dump tanks using 100-150 ppm of sodium hypochlorite $(\mathrm{NaOCl})[14]$. However, the efficacy of $\mathrm{NaOCl}$ diminishes as greater amounts of organic materials build up in the sanitizing solution [15]. Pathogen control is also reliant on maintaining a narrow $\mathrm{pH}$ range [16]. In addition, the chlorine treatment can potentially produce carcinogenic compounds, such as trichloramines, as byproducts of the treatment posing public health risks $[17,18]$. Chlorine dioxide $\left(\mathrm{ClO}_{2}\right)$ has gained popularity within the last couple of decades to disinfect drinking water and wastewater, and to sanitize fresh produce and poultry [19]. $\mathrm{ClO}_{2}$ has 2.5 times the oxidizing capability as $\mathrm{Cl}_{2}$ and may be an effective alternative produce sanitizer [20]. $\mathrm{ClO}_{2}$ offers similar sanitation efficacy as chlorine-based sanitizers while requiring far less concentration in a wide $\mathrm{pH}$ range (3-8) [21]. Additionally, $\mathrm{ClO}_{2}$ does not have issues related to the production of carcinogenic byproducts [22].

Previous studies have demonstrated the efficacy of $\mathrm{ClO}_{2}$ in reducing human pathogens including Shiga-toxin-producing Escherichia coli, Salmonella enterica, Listeria monocytogenes, Pseudomonas aeruginosa, Staphylococcus aureus, and Yersinia enterocolitica on a variety of produce [19]. The microbial death is believed to be due to oxidation of sulfhydryl groups on cell-surface proteins and increased permeability of the outer membrane [23]. Another mechanism is its influence on internal components of the cells such as proteins and nucleic acids as well as interfering protein synthesis [19,24]. At $5 \mathrm{ppm}$, aqueous $\mathrm{ClO}_{2}$ has demonstrated cross-contamination control of Salmonella, Escherichia coli O157:H7, and Erwinia carotovora in washing produce $[16,25]$. Blueberries sanitized with $5 \mathrm{ppm}$ aqueous $\mathrm{ClO}_{2}$ were found to have $2.24 \mathrm{log} \mathrm{CFU} / \mathrm{g}$ reduction in L. monocytogenes after $30 \mathrm{~min}$ of treatment with further treatment time resulting in similar levels of reduction [26]. Green peppers exhibited a $6.45 \mathrm{log}$ CFU/g reduction in E. coli $\mathrm{O} 157: \mathrm{H} 7$ after $30 \mathrm{~min}$ of $1.24 \mathrm{mg} / \mathrm{L}$ aqueous $\mathrm{ClO}_{2}$ treatment [13]. The objective of this study was to evaluate the efficacy of aqueous chlorine dioxide on reducing bacterial pathogens (E. coli O157:H7, Salmonella spp., and L. monocytogenes) from sweet potatoes and its role in minimizing cross-contamination during washing.

\section{Materials and Methods}

\subsection{Produce Material}

Fresh Beauregard sweet potatoes (Ipomoea batatas) sourced from Black Gold farms in Delhi, Louisiana were held at $4{ }^{\circ} \mathrm{C}$ for no longer than 12 weeks. Freshly harvested sweet potatoes collected before the curing step, without removing the surface soil were also used to examine the difference between the cured and uncured samples. Sweet potatoes with average surface areas of $274-293 \mathrm{~cm}^{2}$ were selected for the experiment. 


\subsection{Bacterial Strains}

Several strains of S. enterica, E. coli O157:H7, L. monocytogenes derived from outbreaks as well as a nonpathogenic strain of Enterococcus spp., were used in this study. These pathogenic strains were generously supplied by Dr. Michelle D. Danyluk at the University of Florida. A cocktail of Salmonella enterica (Anatum strain 1715a, Enteritidis PT 30, and Enteritidis PT 9c Strain RM4635), E. coli O157:H7 (Odwalla strain 223, CDC 658, and H1730), and Listeria monocytogenes (101M serotype 4b, Scott A serotype $4 b$, and V7 serotype $1 / 2 a$ ) were used in this study. All serotypes were routinely grown in tryptic soy broth (TSB) (Hardy Diagnostics, Santa Maria, CA) at $37^{\circ} \mathrm{C}$ for $24 \mathrm{~h}$. The bacterial cultures were stored in glycerol (70:30, vol/vol, culture: glycerol) at $-80^{\circ} \mathrm{C}$ prior to usage.

\subsection{Preparation of Inoculum}

Each frozen culture was activated by three consecutive culture transfers ( $24 \mathrm{~h}$ each) to respective broth maintaining $37^{\circ} \mathrm{C}$ [27]. The TSB (BD Difco, Sparks, MD, USA) was used for the activation of S. enterica and E. coli O157:H7 and TSB with $0.6 \%$ yeast extract (BD Difco, Sparks, MD, USA) for L. monocytogenes. The cocktail of pathogens was prepared by mixing $10 \mathrm{~mL}$ of each serotype broth into $50 \mathrm{~mL}$ centrifuge tubes and vortexed for $2 \mathrm{~s}$. Cells were harvested via centrifugation (Allegra X-15R, Beckman Coulter, Indianapolis, IN, USA) at $6500 \mathrm{rpm}$ for $5 \mathrm{~min}$ and the supernatant was decanted. Cell pellets were washed in $10 \mathrm{~mL}$ of sterile $1 \times$ phosphate buffer saline (PBS) (Hardy Diagnostics, Santa Maria, CA, USA), centrifuged at $6500 \mathrm{rpm}$ for $5 \mathrm{~min}$, and resuspended in $5 \mathrm{~mL}$ of sterile $1 \times$ PBS. To prepare the inocula, the cell suspension cocktails were diluted and adjusted to approximately $10^{8}-10^{9} \mathrm{CFU} / \mathrm{mL}$.

\subsection{Inoculation of Sweet Potatoes}

Sweet potatoes were spot inoculated with $500 \mu \mathrm{L}$ of the inoculum. The inoculum was gradually introduced at a rate of $100 \mu \mathrm{L}$ aliquots on the upper surface of the sweet potatoes to minimize inoculum loss from runoff. Sweet potatoes were then air-dried for $1.5 \mathrm{~h}$ inside a biosafety cabinet to allow for bacterial attachment. During the study, the initial pathogen level on inoculated sweet potatoes was 4.2 to $5.7 \log \mathrm{CFU} / \mathrm{cm}^{2}$.

\subsection{Preparation of Aqueous $\mathrm{ClO}_{2}$}

Sodium chlorite solution $(450 \mathrm{~mL}$ of $10 \mu \mathrm{g} / \mu \mathrm{L})$ was mixed with $1 \mathrm{~N}$ hydrochloric acid $(21 \mathrm{~mL})$ in a $1000 \mathrm{~mL}$ PYREX ${ }^{\circledR}$ storage bottle and stored for $1 \mathrm{~h}$ at room temperature with continuous stirring $[28,29]$. The final working concentration of $5 \mathrm{ppm}$ was prepared by diluting the stock solution with distilled water. The concentration was confirmed by direct-reading method (HACH DR 900, Loveland, CO, USA). The $\mathrm{pH}$ value of the $\mathrm{ClO}_{2}$ solutions averaged at 8.67.

\subsection{Aqueous $\mathrm{ClO}_{2}$ Treatment}

Sweet potatoes inoculated with 4.2 to $5.7 \log \mathrm{CFU} / \mathrm{cm}^{2}$ of S. enterica, E. coli O157:H7, or L. monocytogenes and noninoculated sweet potatoes were treated with aqueous $\mathrm{ClO}_{2}(5 \mathrm{ppm})$ or distilled water (control) for 10,20 , and $30 \mathrm{~min}$ at $22 \pm 1{ }^{\circ} \mathrm{C}$. Briefly, sweet potatoes were placed in sterile polypropylene bags $\left(\mathrm{VWR}^{\circledR}\right.$, Radnor, PA, USA) containing the treatment solutions. The bags were then sealed to minimize $\mathrm{ClO}_{2}$ concentration loss and were placed in buckets. Each sample was agitated for $30 \mathrm{~s}$ to ensure treatment contact on sweet potato surfaces.

\subsection{Recovery of Pathogens and Microbiological Analyses}

Three additional controls that received no treatment were used in this study. The first control was conducted with a duplicate of noninoculated, untreated sweet potatoes used to detect background microbes and potential pathogens. The second control was conducted with two duplicates of inoculated, untreated sweet potatoes used to determine the initial pathogen levels of treated samples. 
The third control was conducted with a duplicate of inoculated, untreated sweet potatoes used to determine the surviving pathogen levels following the end of the treatments. Treatment solutions from aqueous $\mathrm{ClO}_{2}$ and water treatments were sampled for microbiological analysis. After treatment, inoculated and noninoculated sweet potato samples were aseptically transferred into a stomacher bag (Nasco Whirl-pak, Fort Atkinson, WI, USA) with $100 \mathrm{~mL}$ sterile $0.1 \%$ peptone water (Hardy Diagnostics, Santa Maria, CA, USA). Samples were gently massaged for 2 min to dislodge attached pathogens. Serial 10 -fold dilutions were prepared in $0.1 \%$ peptone water. Dilutions were spread plated in duplicates on selective media with Xylose Lysine Deoxycholate agar (XLD) (BD Difco, Sparks, MD, USA) for S. enterica, Sorbitol MacConkey Agar (SMAC) (BD Difco, Sparks, MD, USA) supplemented with Cefixime-Tellurite Supplement (CT) (HiMedia Laboratories, Mumbai, India) for E. coli O157:H7, and Oxford Agar base (BD Difco, Sparks, MD, USA) for L. monocytogenes. Plates were incubated at $37^{\circ} \mathrm{C}$ for $24 \mathrm{~h}$. Enumerated colony results were expressed as $\log \mathrm{CFU} / \mathrm{cm}^{2}$.

\subsection{Statistical Analysis}

The pathogen populations (CFU) recovered from sweet potatoes and treatment solutions were converted to $\log \mathrm{CFU} / \mathrm{cm}^{2}$ or $\mathrm{ml}$. Each experiment was performed three times independently. The data was analyzed by ANOVA test using Statistical Analysis Software (SAS) with Tukey's post hoc test to determine mean differences $(p<0.05)$ (SAS Institute, Cary, NC, USA).

\section{Results}

\subsection{Effects of Aqueous $\mathrm{ClO}_{2}$ Treatment on Salmonella Enterica}

The effect of 5 ppm aqueous $\mathrm{ClO}_{2}$ treatment on reducing Salmonella populations inoculated on sweet potato surfaces was investigated with treatment times ranging from 10 to $30 \mathrm{~min}$ (Figure 1). The level of reduction in S. enterica population increased with an increase in exposure time. The level of reduction was $1.67,2.14$, and $2.37 \log \mathrm{CFU} / \mathrm{cm}^{2}$ at 10,20 , and $30 \mathrm{~min}$ of exposure, respectively. Water resulted in the reduction of the population by $1.22 \log \mathrm{CFU} / \mathrm{cm}^{2}$ at $10 \mathrm{~min}$. However, no significant reduction was observed with an increase in exposure time with water, up to $30 \mathrm{~min}$.

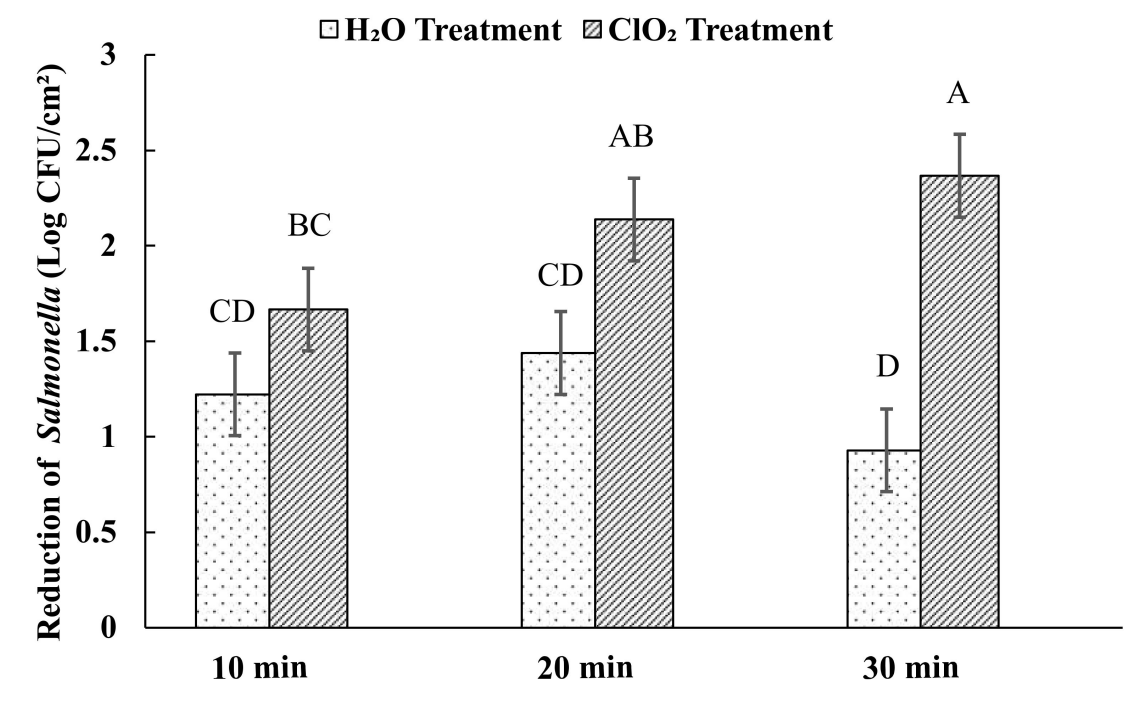

Treatment Time

Figure 1. Effects of aqueous $\mathrm{ClO}_{2}$ and water treatment on the reduction of Salmonella spp. Reduction of Salmonella spp. seeded on sweet potato surfaces was evaluated after 10, 20, and $30 \mathrm{~min}$ of aqueous $\mathrm{ClO}_{2}$ (5 ppm) and water treatments at $22 \pm 1{ }^{\circ} \mathrm{C}$. Each bar diagram represents average counts \pm standard error. Different uppercase letters on the top of the diagrams means that the reductions between the treatments and times were significantly different $(p<0.05)$. 
The disinfectant efficacy of aqueous $\mathrm{ClO}_{2}$ could be higher in water. The treatment with $5 \mathrm{ppm}$ $\mathrm{ClO}_{2}$ resulted in the reduction of $S$. enterica level by $\geq 5-\log$ within $6 \mathrm{~s}$ [30]. However, the efficacy of the sanitizer is drastically reduced on produce surfaces. Although complete elimination of pathogens from fresh produce is not possible using this sanitizer at acceptable concentration, its use in produce industry may help minimize produce safety risks by reducing the pathogens level and controlling cross-contamination between the products and the batches [22,30,31]. To our knowledge, there are no published findings on the sanitizing efficacy of aqueous $\mathrm{ClO}_{2}$ specifically on sweet potatoes. However, some studies have been published on other fruits and leafy vegetables. In a study with iceberg lettuce inoculated with S. typhimurium, similar results were observed after 10 min treatment with aqueous $\mathrm{ClO}_{2}$ [31]. Pathogen levels were reduced by $1.64 \log \mathrm{CFU} / \mathrm{g}$ after the treatment with continuous mild agitation. Likewise, blueberries inoculated with S. typhimurium exhibited similar levels of reduction (1.93 log CFU/g) after $20 \mathrm{~min}$ of $5 \mathrm{ppm}$ aqueous $\mathrm{ClO}_{2}$ treatment [26]. On apples, a total of up to $2 \log$ reduction in Salmonella population was observed after $10 \mathrm{~min}$ of treatment with a similar concentration of the sanitizer [32]. Cherry tomatoes inoculated with S. typhimurium exhibited a $2.53 \log \mathrm{CFU} / \mathrm{g}$ reduction after a $5 \mathrm{~min}$ treatment using $10 \mathrm{ppm}$ aqueous $\mathrm{ClO}_{2}$ [33]. The treatment with $15 \mathrm{ppm}$ of $\mathrm{ClO}_{2}$ resulted in the reduction of $S$. typhimurium by $3.32 \log$ in $20 \mathrm{~min}$ on blueberry samples [26]. The treatment was more efficient on tomatoes samples. $\mathrm{ClO}_{2}$ of $20 \mathrm{ppm}$ reduced S. enterica population by $5 \log$ in $1 \mathrm{~min}$ [30]. While mungbean sprout required $100 \mathrm{ppm}$ to eliminate the S. typhimurium by $3 \log$ in $5 \mathrm{~min}$ [34]. The variations in the level of reductions between the studies can be attributed to differences in aqueous $\mathrm{ClO}_{2}$ concentrations and types of produce. The efficacy of the treatment increased with increase in the concentration of the aqueous $\mathrm{ClO}_{2}$ [31]. Our results indicated that, unlike water treatment, an increase in the $\mathrm{ClO}_{2}$ treatment time increased the level of reduction in Salmonella populations, with more than 2 log reduction after $20 \mathrm{~min}$ of exposure.

\subsection{Effects of Aqueous $\mathrm{ClO}_{2}$ Treatment on E. coli O157:H7}

The effect of $5 \mathrm{ppm}$ aqueous $\mathrm{ClO}_{2}$ on $\mathrm{E}$. coli $\mathrm{O} 157: \mathrm{H} 7$ on sweet potato surfaces was investigated with treatment times ranging from 10 to $30 \mathrm{~min}$ (Figure 2). The $\mathrm{ClO}_{2}$ treatment for $10 \mathrm{~min}$ resulted in the reduction of the population by $1.78 \log \mathrm{CFU} / \mathrm{cm}^{2}$. At $20 \mathrm{~min}$ of treatment, the reduction was by $2.0 \log \mathrm{CFU} / \mathrm{cm}^{2}$, which was significantly higher than water $\left(1.31 \log \mathrm{CFU} / \mathrm{cm}^{2}\right)$. However, after $30 \mathrm{~min}$, water had a similar level of reduction as compared to $\mathrm{ClO}_{2}$.

Some studies showed similar levels of reduction in E. coli O157: H7 populations on produce surfaces due to $\mathrm{ClO}_{2}$ and water washing. It was reported that water washing for 30 min reduced E. coli O157:H7 levels by up to $2.4 \log \mathrm{CFU}$ on green peppers [13]. Iceberg lettuce leaves inoculated with E. coli O157:H7 resulted in 1.98 and $1.46 \log \mathrm{CFU} / \mathrm{g}$ reduction after $10 \mathrm{~min}$ of $5 \mathrm{ppm}$ aqueous $\mathrm{ClO}_{2}$ and distilled water treatment, respectively [31]. Another study observed the reduction of the population of this pathogen by $1.2 \log$ after $5 \mathrm{~min}$ of treatment with $\mathrm{ClO}_{2}$ of $10 \mathrm{ppm}$ [35]. Increase in the concentration of the sanitizer to $20 \mathrm{ppm}$ and the time to $15 \mathrm{~min}$ resulted in the reduction by $1.7 \log$ [36]. On apples, the reduction was around $1 \log$ after the treatment with 5 ppm for $10 \mathrm{~min}$ [32]. However, the effect of treatments could be variable with the type of produce and their surface characteristics. Higher levels of reductions were observed on ( $\sim 6 \log \mathrm{CFU} / \mathrm{g}$ ) apples, whole lettuce, strawberries, and cantaloupes by 5 ppm of aqueous $\mathrm{ClO}_{2}$ with exposure for $5 \mathrm{~min}$ [37]. The water washing resulted in the reduction of E. coli O157:H7 levels by up to $1.7 \log$ CFU on injured surfaces and by up to $2.4 \log$ CFU on uninjured green pepper surfaces [13]. The sweet potatoes used in this study were free of lesions, injuries, and scars. Further study using sweet potatoes with injured surfaces and with different surface characteristics could help to better understand the variability in the sanitizing efficacy of aqueous $\mathrm{ClO}_{2}$ specifically on sweet potatoes. 


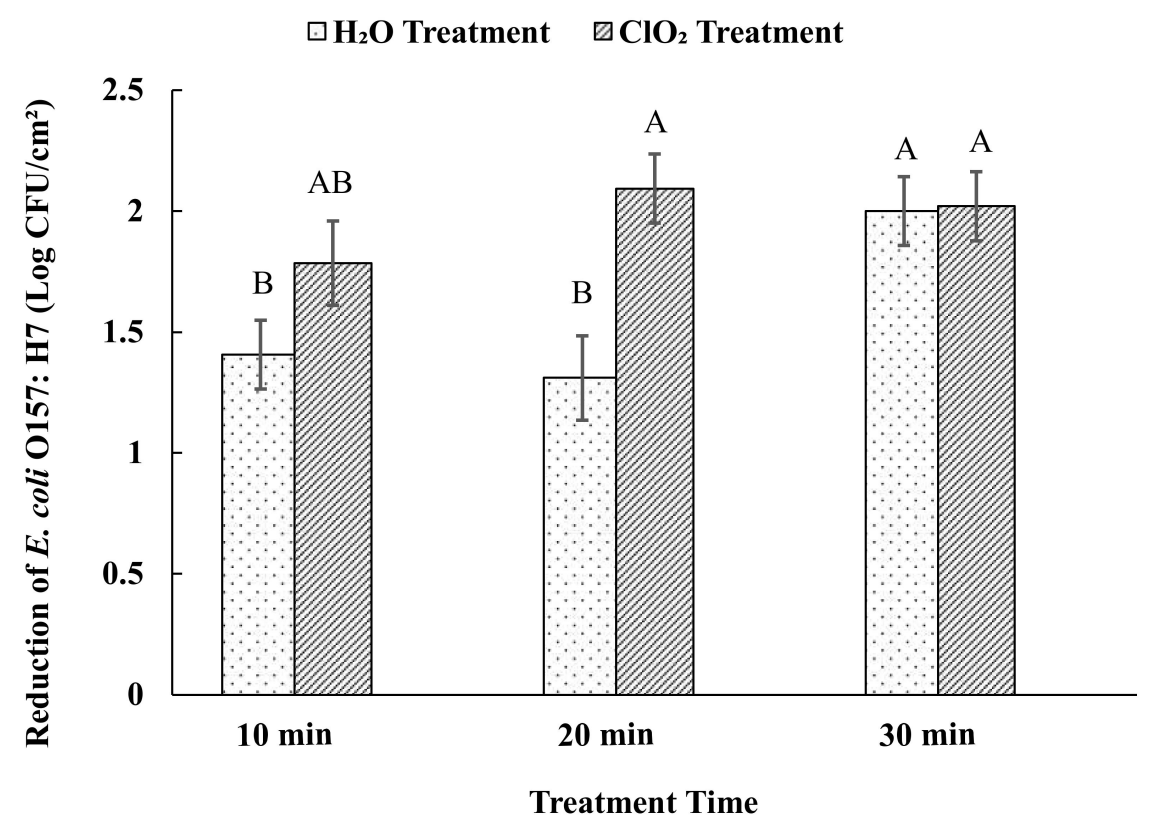

Figure 2. Effects of aqueous $\mathrm{ClO}_{2}$ and water treatment on the reduction of E. coli O157:H7. Reduction of $\mathrm{E}$. coli $\mathrm{O} 157: \mathrm{H7}$ on sweet potato surfaces after aqueous $\mathrm{ClO}_{2}$ treatment (5 ppm) for 10, 20, and $30 \mathrm{~min}$ and water treatment at $22 \pm 1{ }^{\circ} \mathrm{C}$. Each bar diagram represents average counts \pm standard error. Different uppercase letters on the top of the diagrams means that the reductions between the treatments and times were significantly different $(p<0.05)$.

\subsection{Effects of Aqueous $\mathrm{ClO}_{2}$ Treatment on Listeria Monocytogenes}

Reduction of L. monocytogenes on sweet potato surfaces increased with time, up to $30 \mathrm{~min}$ (Figure 3). Aqueous $\mathrm{ClO}_{2}$ treatment at $30 \mathrm{~min}$ had the greatest effect in reducing L. monocytogenes $\left(1.98 \log \mathrm{CFU} / \mathrm{cm}^{2}\right)$. Although there was a higher reduction on $\mathrm{ClO}_{2}$ treated samples compared to the controls (water treated) at $10 \mathrm{~min}$, a significantly higher reduction on those samples was observed only after $20 \mathrm{~min}$. Similar to the effect on Salmonella, there was no significant difference between reductions due to water treatment among the three treatment times.

In a study with iceberg lettuce leaves contaminated with L. monocytogenes, reductions from approximately $7 \log \mathrm{CFU} / \mathrm{g}$ to $5.36 \log \mathrm{CFU} / \mathrm{g}$ were observed within $10 \mathrm{~min}$ of $5 \mathrm{ppm}$ aqueous $\mathrm{ClO}_{2}$ treatment with light and continuous agitation [31]. This finding closer resembles the L. monocytogenes reduction achieved in our study after $20 \mathrm{~min}$ of treatment. As only $30 \mathrm{~s}$ of agitation was applied to treated samples at the start of the treatment, greater reduction may have been exhibited had continuous agitation been incorporated. Uninjured green peppers spot inoculated with L. monocytogenes observed $3.7 \mathrm{log}$ reduction after $30 \mathrm{~min}$ of $3 \mathrm{ppm}$ aqueous $\mathrm{ClO}_{2}$ treatment, far greater than our $30 \mathrm{~min}$ treatment result of $1.98 \log \mathrm{CFU} / \mathrm{cm}^{2}$ [38]. In the same study, uninjured green pepper surfaces observed a $1.4 \mathrm{log}$ reduction of $L$. monocytogenes populations after $30 \mathrm{~min}$ of water washing. However, our findings after $30 \mathrm{~min}$ of water washing $\left(0.49 \log \mathrm{CFU} / \mathrm{cm}^{2}\right)$ showed more similarities to the $0.4 \log$ reduction observed on injured green pepper surfaces [38]. The efficacy of the $\mathrm{ClO}_{2}$ treatment was different between the studies. The treatment of cabbage and lettuce with $5 \mathrm{ppm}$ of $\mathrm{ClO}_{2}$ for $10 \mathrm{~min}$ resulted in the reduction of this pathogen by $0.8 \mathrm{log}$ [39]. On blueberry samples, $\mathrm{ClO}_{2}$ of $15 \mathrm{ppm}$ reduced the population by $4.88 \mathrm{log}$ after $120 \mathrm{~min}$ of exposure [26]. While on mungbean sprouts, $\mathrm{ClO}_{2}$ of $100 \mathrm{ppm}$ could reduce the population by $1.5 \mathrm{log}$ after $5 \mathrm{~min}$ of treatment [34]. The differences in the efficacy between the studies may be attributed to the type of the produce used, the condition of the produce, bacterial strains and the study design. Some studies have already demonstrated that the type of pathogen or the strain could be one of the important factors influencing the efficacy of the sanitizers [22,30,31]. Surface properties of produce also has been found to have an influence on the efficacy of the sanitizers. 
Surface hydrophobicity was found to be an important factor in determining the inactivation of E. coli O157:H7, S. typhimurium, and L. monocytogenes by $\mathrm{ClO}_{2}$ gas [40].

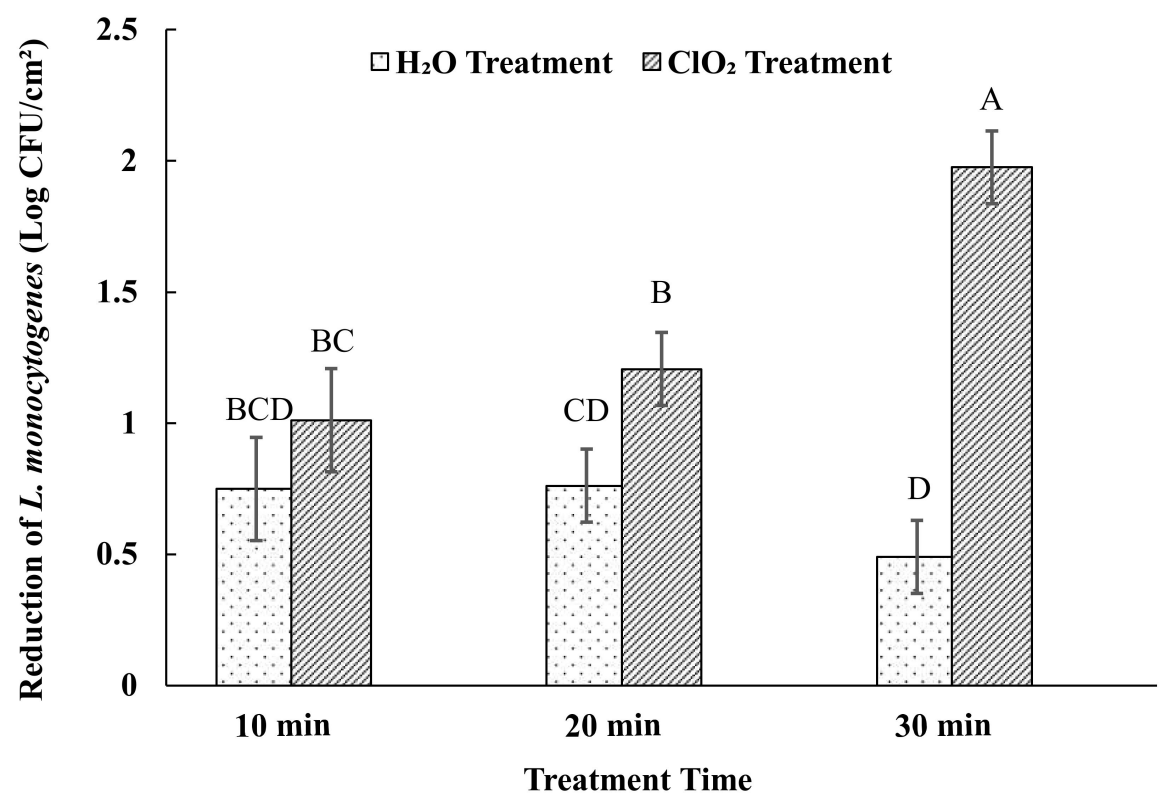

Figure 3. Effects of aqueous $\mathrm{ClO}_{2}$ and water treatment on the reduction of L. monocytogenes. Reduction of L. monocytogenes on sweet potato surfaces after $5 \mathrm{ppm}$ aqueous $\mathrm{ClO}_{2}$ treatment for 10, 20, and $30 \mathrm{~min}$ and water treatment at $22 \pm 1{ }^{\circ} \mathrm{C}$. Each bar diagram represents average counts \pm standard error. Different uppercase letters on the top of the diagrams means that the reductions between the treatments and times were significantly different $(p<0.05)$.

\subsection{Influences of Aqueous $\mathrm{ClO}_{2}$ on Cross Contamination of Noninoculated Sweet Potatoes}

The $\mathrm{ClO}_{2}$ was extremely effective in controlling bacterial levels from wash water (Figure 4). Pathogens from aqueous $\mathrm{ClO}_{2}$ treatment wash solutions were below the detectable limit of the test following 10, 20, and $30 \mathrm{~min}$ treatments. However, pathogens were detected up to $4.92 \mathrm{log} \mathrm{CFU} / \mathrm{mL}$ from wash water without $\mathrm{ClO}_{2}$. Water treatment wash solutions recovered the greatest pathogen population from 4.16 to $4.92 \log \mathrm{CFU} / \mathrm{mL}$ for E. coli O157:H7. Water treatment wash solutions from treating Salmonella and L. monocytogenes recovered 3.81 to $3.96 \log \mathrm{CFU} / \mathrm{mL}$ and 3.49 to $3.59 \log \mathrm{CFU} / \mathrm{mL}$, respectively. These results suggest that using $\mathrm{ClO}_{2}$ during the washing of sweet potatoes can significantly reduce the risk of cross-contamination. In addition, $\mathrm{ClO}_{2}$ concentrations were below 3 ppm on sweet potatoes after $30 \mathrm{~min}$ of treatment, meeting the maximum residual surface concentration approved by the United States Food and Drug Administration (FDA) [41].

Use of $\mathrm{ClO}_{2}$ resulted in no recovery of the pathogens on noninoculated sweet potatoes when washed with inoculated samples (Table 1). Our results concurred with the findings reported by other studies. No recoverable E. coli O157:H7, Salmonella enterica and S. typhimurium was observed from noninoculated red chard baby leaves washed together with inoculated red chard baby leaves in 3 ppm aqueous $\mathrm{ClO}_{2}$ [16]. Similarly, $5 \mathrm{ppm}$ aqueous $\mathrm{ClO}_{2}$ prevented the cross-contamination of tomatoes [25]. However, water wash contributed to the cross-contamination of noninoculated sweet potatoes by up to 3.40, 2.97 and $3.47 \log \mathrm{CFU} / \mathrm{cm}^{2}$ of Salmonella, E. coli O157: $\mathrm{H7}$ and L. monocytogenes, respectively (Table 1). In another study, wash water contaminated with $6.7 \mathrm{log}$ CFU/mL of Salmonella spp. and $5.5 \log$ CFU/mL of Erwinia spp., transferred 4.1 and $2.8 \log \mathrm{CFU} / \mathrm{cm}^{2}$ of Salmonella spp. and Erwinia spp., respectively to tomatoes within $1 \mathrm{~min}$ of washing [25]. The $\mathrm{ClO}_{2}$ of $5 \mathrm{ppm}$ was able to prevent the cross-contamination of tomatoes with Salmonella and Erwinia [30]. The results indicated that using $\mathrm{ClO}_{2}$ as low as 5 ppm could significantly reduce the risk of cross-contamination during postharvest washing. 


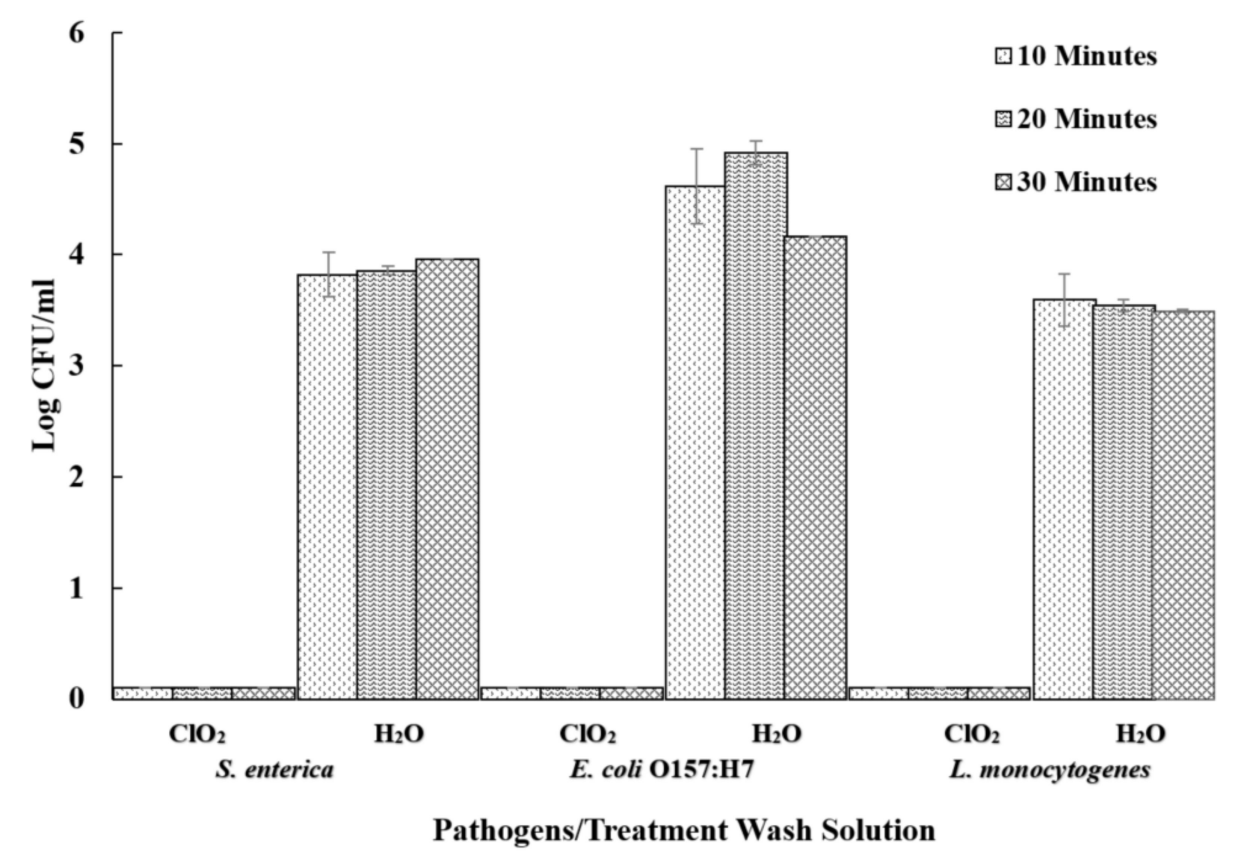

Figure 4. The recovery of pathogens from wash water. Pathogens recovered from wash solution following aqueous $\mathrm{ClO}_{2}$ treatment (5 ppm) for 10, 20, and $30 \mathrm{~min}$ and water treatment at $22 \pm 1{ }^{\circ} \mathrm{C}$.

Table 1. Cross-contamination of pathogens on noninoculated sweet potatoes washed together with inoculated sweet potatoes with or without aqueous chlorine dioxide.

\begin{tabular}{cccc}
\hline \multirow{2}{*}{ Pathogen } & Treatment Time & \multicolumn{2}{c}{ Recovery Average of Pathogens $\left(\mathbf{l o g} \mathbf{C F U} / \mathbf{c m}^{2}\right.$ ) } \\
\cline { 3 - 4 } & & Aqueous $\mathbf{C l O}_{\mathbf{2}}$ & Water Treatment \\
\hline \multirow{3}{*}{ Salmonella } & 10 & ND & $3.40 \pm 0.0$ \\
& 20 & ND & $2.84 \pm 0.2$ \\
& 30 & ND & $2.84 \pm 0.1$ \\
\multirow{2}{*}{ E. coli O157:H7 } & 10 & ND & $2.97 \pm 0.7$ \\
& 20 & ND & $2.95 \pm 0.5$ \\
& 30 & ND & $2.38 \pm 0.3$ \\
L. monocytogenes & 10 & ND & $3.00 \pm 0.6$ \\
& 20 & ND & $3.18 \pm 0.5$ \\
& 30 & ND & $3.47 \pm 1.1$ \\
\hline
\end{tabular}

$\mathrm{ND}=$ Not Detectable

\subsection{Effects of Aqueous $\mathrm{ClO}_{2}$ on E. coli O157: $\mathrm{H7}$ and Salmonella on Freshly Harvested Sweet Potatoes}

The effect of $\mathrm{ClO}_{2}$ and water treatment on E. coli O157: $\mathrm{H} 7$ and Salmonella inoculated on the freshly harvested local sweet potatoes is shown in Figure 5. As the sweet potatoes were collected before the curing step, the level of soil on them was higher than on the samples used in previous studies. The effect of the treatments on reducing the level of Salmonella and E. coli O157: H7 on these fruits was lower compared to on cured sweet potatoes. The aqueous $\mathrm{ClO}_{2}$ treatment for $10 \mathrm{~min}$ reduced the level of Salmonella and E. coli O157: H7 by 1.46 and $1.20 \log \mathrm{CFU} / \mathrm{cm}^{2}$, respectively. The effect of water treatment was by 0.79 and $0.77 \log \mathrm{CFU} / \mathrm{cm}^{2}$, respectively, which was not significantly different from the $\mathrm{ClO}_{2}$ treatment.

This study was aimed to consider freshly harvested sweet potatoes with higher levels of soil and bruises on the surfaces. Mechanical harvesting may result in bruises on the surfaces. As sweet potatoes we used in this study skipped the curing step, if there were bruises on these fruits, there was not enough time for the healing [42]. The injuries on produce surfaces may reduce the efficacy of the sanitizers [22]. Aqueous $\mathrm{ClO}_{2}(3 \mathrm{ppm})$ reduced the L. monocytogenes population by $3.7 \log \mathrm{CFU}$ when 
bell pepper surfaces were not injured and by 0.44 when injured [38]. Reduced efficacy of the treatments in our study may be due to a higher level of bruises and attached soiled particles which may have allowed bacterial cells to hide better in the surfaces limiting the access to the sanitizer solutions $[43,44]$. However, a further rigorous study is needed to better understand the influence of individual factors on the efficacy of the sanitizer.

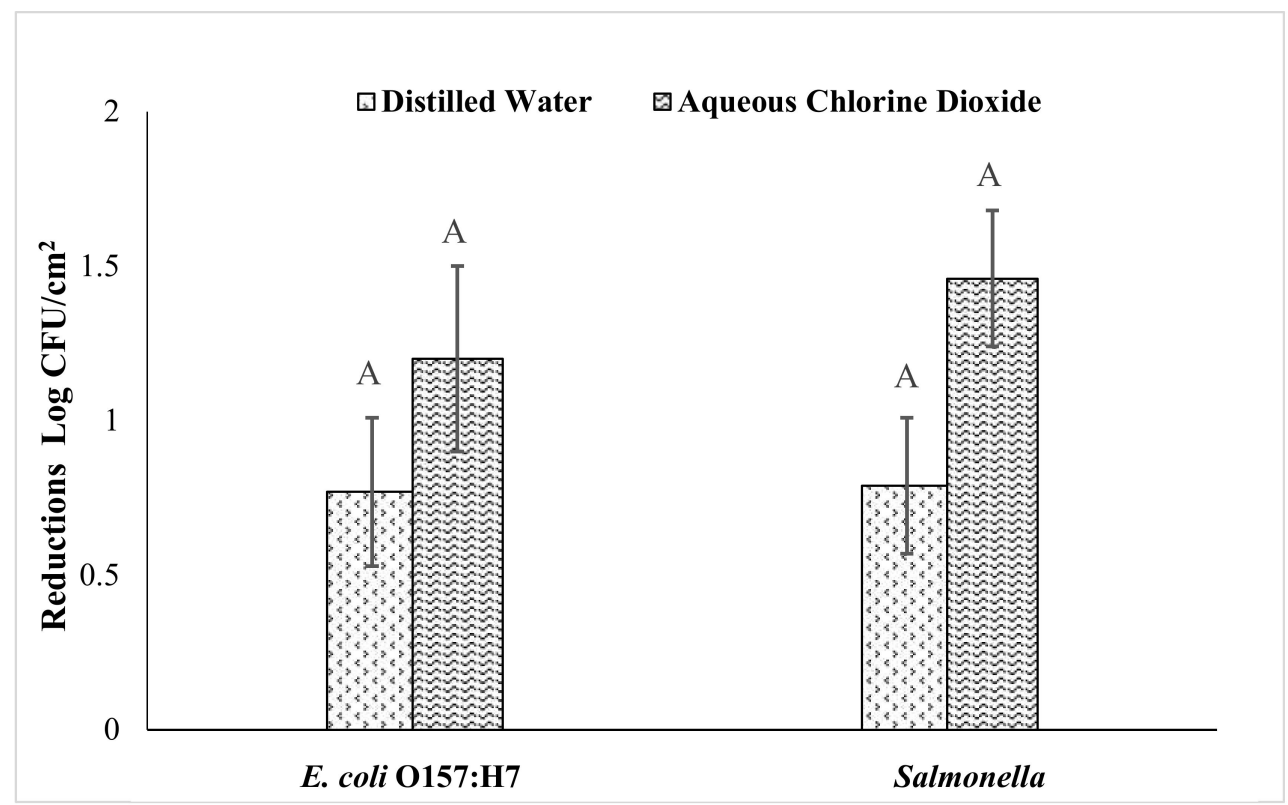

Figure 5. Effects of aqueous $\mathrm{ClO}_{2}$ and water treatment on the reduction of E. coli O157: $\mathrm{H7}$ and Salmonella on freshly harvested sweet potatoes. Reduction of E. coli O157: H7 and Salmonella on freshly harvested sweet potatoes after aqueous $\mathrm{ClO}_{2}$ treatment $(5 \mathrm{ppm})$ and water treatment for $10 \mathrm{~min}$ at $22 \pm 1{ }^{\circ} \mathrm{C}$. The data are presented as average counts \pm standard error. Same uppercase letters on the top of the diagrams indicate no significant difference $(p<0.05)$ in between the treatments.

The efficacy of the treatment has been increased by the combination of other strategies. The combination of aqueous $\mathrm{ClO}_{2}$ and fumaric acid increased the efficacy of the treatment against E. coli O157:H7, S. typhimurium, and L. monocytogenes inoculated on broccoli sprouts [45]. The combined treatments of $\mathrm{ClO}_{2}$ and ultrasound was found to have a role in maintaining postharvest storage quality of plum fruit [46]. Use of ultraviolet-C along with $\mathrm{ClO}_{2}$ was also effective in inhibiting microorganisms and maintaining shelf-life of fresh produce [47]. Another study evaluated the efficacy of $\mathrm{ClO}_{2}$ plus chitosan coating and found that this strategy could maintain the quality of fresh-cut bamboo shoot and extend their postharvest life [48]. These strategies had no significant effect on the sensory quality of the products. Furthermore, storage of mungbean sprouts using atmosphere packaging (MAP) followed by the treatment reduced the microbial population [34]. These results indicated that there is a room for the improvement with the treatment by combining other strategies even for sweet potatoes.

Overall, the application of chlorine dioxide at $5 \mathrm{ppm}$ significantly reduced the pathogen' levels during the postharvest washing of sweet potatoes. In addition, aqueous $\mathrm{ClO}_{2}$ can control cross-contamination in wash solutions, reducing the risk of cross-contamination of pathogens to uncontaminated sweet potatoes. The final concentration of $\mathrm{ClO}_{2}$ in sweet potatoes was below $3 \mathrm{ppm}$ after 30 min of treatment, meeting the maximum residual surface concentration approved by the FDA [41]. Future research should incorporate longer and more vigorous agitation during treatment to better simulate conditions in processing facilities as well as sensory studies to evaluate whether aqueous chlorine dioxide at $5 \mathrm{ppm}$ affects the desirable sensory qualities of sweet potatoes. 
Author Contributions: Conceptualization, A.A.; data curation, P.L. and V.S.C.; funding acquisition, A.A.; investigation, P.L. and V.S.C.; methodology, P.L. and A.A.; project administration, A.A.; supervision, M.E.J., J.M.K. and A.A.; writing—original draft, P.L.; writing—review and editing, V.S.C., M.E.J., J.M.K. and A.A. All authors have read and agreed to the published version of the manuscript.

Funding: This work was supported by the USDA Specialty Crop Block Program PO\#2000241663 and PO\#2000317761 and the National Institute of Food and Agriculture, Hatch project 1006167.

Acknowledgments: The authors would like to thank Veerachandra Kranti Yemmireddy, Assem Abolmatty, Karuna Kharel, Cameron Cason, Brett Riviere, Daniela Zelaya, Janny Mendoza, Yu Han and David Huynh for their help during editing the manuscript and sample analysis.

Conflicts of Interest: The authors declare no conflict of interest.

\section{References}

1. Prakash, P.; Kishore, P.; Jaganathan, D.; Immanual, S.; Sivakumar, P. The Status, Performance and Impact of sweet potato cultivation on farming communities of Odisha, India. In Proceedings of the 2018 Conference, Vancouver, BC, Canada, 28 July-2 August 2018. [CrossRef]

2. Prakash, C. Sweet potato biotechnology: Progress and potential. Biotechnol. Dev. Monit. 1994, 18, 1819-1822.

3. Low, J.W.; Arimond, M.; Osman, N.; Cunguara, B.; Zano, F.; Tschirley, D. A food-based approach introducing orange-fleshed sweet potatoes increased vitamin A intake and serum retinol concentrations in young children in rural Mozambique. J. Nutr. 2007, 137, 1320-1327. [CrossRef] [PubMed]

4. Peet, M. Sustainable Practices for Vegetable Production in the South; Focus Publishing, R. Pullins Co: Newburyport, MA, USA, 1996.

5. Mohammad, Z.H.; Yu, H.; Neal, J.A.; Gibson, K.E.; Sirsat, S.A. Food Safety Challenges and Barriers in Southern United States Farmers Markets. Foods 2020, 9, 12. [CrossRef] [PubMed]

6. Lynch, M.F.; Tauxe, R.V.; Hedberg, C.W. The growing burden of foodborne outbreaks due to contaminated fresh produce: Risks and opportunities. Epidemiols. Infect. 2009, 137, 307-315. [CrossRef] [PubMed]

7. Hanning, I.B.; Nutt, J.; Ricke, S.C. Salmonellosis outbreaks in the United States due to fresh produce: Sources and potential intervention measures. Foodborne Pathog. Dis. 2009, 6, 635-648. [CrossRef] [PubMed]

8. Chhetri, V.S.; Fontenot, K.; Strahan, R.; Yemmireddy, V.K.; Parraga Estrada, K.J.; Adhikari, A. Effect of surrounding vegetation on microbial survival or die-off on watermelon surface in an agriculture setting. J. Food Saf. 2018, 38, e12520. [CrossRef]

9. Islam, M.; Doyle, M.P.; Phatak, S.C.; Millner, P.; Jiang, X. Survival of Escherichia coli O157: H7 in soil and on carrots and onions grown in fields treated with contaminated manure composts or irrigation water. Food Microbiol. 2005, 22, 63-70. [CrossRef]

10. Angulo, F.J.; Getz, J.; Taylor, J.P.; Hendricks, K.A.; Hatheway, C.L.; Barth, S.S.; Solomon, H.M.; Larson, A.E.; Johnson, E.A.; Nickey, L.N. A large outbreak of botulism: The hazardous baked potato. J. Infect. Dis. 1998, 178, 172-177. [CrossRef]

11. Sobel, J.; Tucker, N.; Sulka, A.; McLaughlin, J.; Maslanka, S. Foodborne botulism in the United States, 1990-2000. Emerg. Infect. Dis. 2004, 10, 1606. [CrossRef]

12. Chhetri, V.S.; Janes, M.E.; King, J.M.; Doerrler, W.; Adhikari, A. Effect of residual chlorine and organic acids on survival and attachment of Escherichia coli O157: H7 and Listeria monocytogenes on spinach leaves during storage. LWT 2019, 105, 298-305. [CrossRef]

13. Han, Y.; Sherman, D.; Linton, R.; Nielsen, S.; Nelson, P. The effects of washing and chlorine dioxide gas on survival and attachment of Escherichia coli O157: H7 to green pepper surfaces. Food Microbiol. 2000, 17, 521-533. [CrossRef]

14. Suslow, T.; Oria, M.; Beuchat, L.; Garrett, E.; Parish, M.; Harris, L.; Farber, J.; Busta, F. Production practices as risk factors in microbial food safety of fresh and fresh-cut produce. Compr. Rev. Food Sci. Food Saf. 2003, 2, 38-77. [CrossRef]

15. Boyette, M.; Ritchie, D.; Carballo, S.; Blankenship, S.; Sanders, D. Chlorination and postharvest disease control. Hort Technol. 1993, 3, 395-400. [CrossRef]

16. Tomás-Callejas, A.; López-Gálvez, F.; Sbodio, A.; Artés, F.; Artés-Hernández, F.; Suslow, T.V. Chlorine dioxide and chlorine effectiveness to prevent Escherichia coli O157: H7 and Salmonella cross-contamination on fresh-cut Red Chard. Food Control 2012, 23, 325-332. [CrossRef] 
17. Richardson, S.; Thruston, A.; Caughran, T.; Collette, T.; Patterson, K. Chemical by-products of chlorine and alternative disinfectants. Food Technol. 1998, 52, 58-61.

18. Shen, C.; Norris, P.; Williams, O.; Hagan, S.; Li, K. Generation of chlorine by-products in simulated wash water. Food Chem. 2016, 190, 97-102. [CrossRef]

19. Bridges, D.F.; Lacombe, A.; Wu, V.C. Integrity of the Escherichia coli O157: H7 Cell Wall and Membranes After Chlorine Dioxide Treatment. Front. Microbiol. 2020, 11, 888. [CrossRef]

20. Benarde, M.A.; Israel, B.M.; Olivieri, V.P.; Granstrom, M.L. Efficiency of chlorine dioxide as a bactericide. Appl. Environ. Microbiol. 1965, 13, 776-780. [CrossRef]

21. Huang, J.; Wang, L.; Ren, N.; Ma, F. Disinfection effect of chlorine dioxide on bacteria in water. Water Res. 1997, 31, 607-613. [CrossRef]

22. Gómez-López, V.M.; Rajkovic, A.; Ragaert, P.; Smigic, N.; Devlieghere, F. Chlorine dioxide for minimally processed produce preservation: A review. Trends Food Sci. Tech. 2009, 20, 17-26. [CrossRef]

23. Praeger, U.; Herppich, W.B.; Hassenberg, K. Aqueous chlorine dioxide treatment of horticultural produce: Effects on microbial safety and produce quality-A review. Crit Rev. Food Sci. Nutr. 2018, 58, 318-333. [CrossRef]

24. Sharma, V.K.; Sohn, M. Reactivity of chlorine dioxide with amino acids, peptides, and proteins. Environ. Chem. Lett. 2012, 10, 255-264. [CrossRef]

25. Pao, S.; Kelsey, D.F.; LONG III, W. Spray washing of tomatoes with chlorine dioxide to minimize Salmonella on inoculated fruit surfaces and cross-contamination from revolving brushes. J. Food Prot. 2009, 72, 2448-2452. [CrossRef]

26. Wu, V.C.; Kim, B. Effect of a simple chlorine dioxide method for controlling five foodborne pathogens, yeasts and molds on blueberries. Food Microbiol. 2007, 24, 794-800. [CrossRef]

27. Adhikari, A.; Bary, A.; Cogger, C.; James, C.; Ünlü, G.; Killinger, K. Thermal and starvation stress response of Escherichia coli O157: H7 isolates selected from agricultural environments. J. Food Prot. 2016, 79, 1673-1679. [CrossRef]

28. Adhikari, A.; Chhetri, V.S.; Bhattacharya, D.; Cason, C.; Luu, P.; Suazo, A. Effectiveness of daily rinsing of alfalfa sprouts with aqueous chlorine dioxide and ozonated water on the growth of Listeria monocytogenes during sprouting. Lett. Appl. Microbiol. 2019, 69, 252-257. [CrossRef]

29. Bang, J.; Kim, H.; Kim, H.; Beuchat, L.; Kim, Y.; Ryu, J.H. Reduction of Escherichia coli O157: H7 on radish seeds by sequential application of aqueous chlorine dioxide and dry-heat treatment. Lett. Appl. Microbiol. 2011, 53, 424-429. [CrossRef]

30. Pao, S.; Kelsey, D.; Khalid, M.; Ettinger, M. Using aqueous chlorine dioxide to prevent contamination of tomatoes with Salmonella enterica and Erwinia carotovora during fruit washing. J. Food Prot. 2007, 70, 629-634. [CrossRef]

31. Kim, Y.J.; Lee, S.H.; Park, J.; Park, J.; Chung, M.; Kwon, K.; Chung, K.; Won, M.; Song, K.B. Inactivation of Escherichia coli O157: H7, Salmonella typhimurium, and Listeria monocytogenes on stored iceberg lettuce by aqueous chlorine dioxide treatment. J. Food Sci. 2008, 73, M418-M422. [CrossRef]

32. Huang, T.S.; Xu, C.; Walker, K.; West, P.; Zhang, S.; Weese, J. Decontamination efficacy of combined chlorine dioxide with ultrasonication on apples and lettuce. J. Food Sci. 2006, 71, M134-M139. [CrossRef]

33. Song, H.-J.; Choi, D.-W.; Song, K.B. Effect of aqueous chlorine dioxide and UV-C treatment on the microbial reduction and color of cherry tomatoes. Hortic. Environ. Biotechnol. 2011, 52, 488. [CrossRef]

34. Jin, H.H.; Lee, S.Y. Combined effect of aqueous chlorine dioxide and modified atmosphere packaging on inhibiting Salmonella typhimurium and Listeria monocytogenes in mungbean sprouts. J. Food Sci. 2007, 72, M441-M445. [CrossRef] [PubMed]

35. Singh, N.; Singh, R.; Bhunia, A.; Stroshine, R. Effect of inoculation and washing methods on the efficacy of different sanitizers against Escherichia coli O157: H7 on lettuce. Food Microbiol. 2002, 19, 183-193. [CrossRef]

36. Singh, N.; Singh, R.; Bhunia, A.; Stroshine, R. Efficacy of chlorine dioxide, ozone, and thyme essential oil or a sequential washing in killing Escherichia coli O157: H7 on lettuce and baby carrots. LWT 2002, 35, 720-729. [CrossRef]

37. Rodgers, S.L.; Cash, J.N.; Siddiq, M.; Ryser, E.T. A comparison of different chemical sanitizers for inactivating Escherichia coli O157: H7 and Listeria monocytogenes in solution and on apples, lettuce, strawberries, and cantaloupe. J. Food Prot. 2004, 67, 721-731. [CrossRef] 
38. Han, Y.; Linton, R.; Nielsen, S.; Nelson, P. Reduction of Listeria monocytogenes on green peppers (Capsicum annuит L.) by gaseous and aqueous chlorine dioxide and water washing and its growth at 7 C. J. Food Prot. 2001, 64, 1730-1738. [CrossRef]

39. Zhang, S.; Farber, J. The effects of various disinfectants against Listeria monocytogenes on fresh-cut vegetables. Food Microbiol. 1996, 13, 311-321. [CrossRef]

40. Park, S.-H.; Kang, D.-H. Influence of surface properties of produce and food contact surfaces on the efficacy of chlorine dioxide gas for the inactivation of foodborne pathogens. Food Control. 2017, 81, 88-95. [CrossRef]

41. FDA. Code of Federal Regulations. Available online: https://www.accessdata.fda.gov/scripts/cdrh/cfdocs/ cfcfr/CFRSearch.cfm?CFRPart=173 (accessed on 1 September 2020).

42. Wills, R.; McGlasson, B.; Graham, D.; Joyce, D.; Rushing, J.W. Postharvest: An introduction to the physiology and handling of fruit, vegetables and ornamentals. J. Veg. Crop Prod. 1999, 4, 83-84.

43. Chhetri, V.S.; Fontenot, K.; Strahan, R.; Yemmireddy, V.K.; Cason, C.; Kharel, K.; Adhikari, A. Attachment strength and on-farm die-off rate of Escherichia coli on watermelon surfaces. PLoS ONE 2019, 14, e0210115. [CrossRef]

44. Gautam, D.; Dobhal, S.; Payton, M.E.; Fletcher, J.; Ma, L.M. Surface survival and internalization of Salmonella through natural cracks on developing cantaloupe fruits, alone or in the presence of the melon wilt pathogen Erwinia tracheiphila. PLoS ONE 2014, 9, e105248. [CrossRef] [PubMed]

45. Kim, Y.; Kim, M.; Song, K. Efficacy of aqueous chlorine dioxide and fumaric acid for inactivating pre-existing microorganisms and Escherichia coli O157: H7, Salmonella typhimurium, and Listeria monocytogenes on broccoli sprouts. Food Control. 2009, 20, 1002-1005. [CrossRef]

46. Chen, Z.; Zhu, C. Combined effects of aqueous chlorine dioxide and ultrasonic treatments on postharvest storage quality of plum fruit (Prunus salicina L.). Postharvest Biol. Technol. 2011, 61, 117-123. [CrossRef]

47. Kim, J.Y.; Kim, H.J.; Lim, G.O.; Jang, S.A.; Song, K.B. The effects of aqueous chlorine dioxide or fumaric acid treatment combined with UV-C on postharvest quality of 'Maehyang'strawberries. Postharvest Biol. Technol. 2010, 56, 254-256. [CrossRef]

48. Yang, H.; Zheng, J.; Huang, C.; Zhao, X.; Chen, H.; Sun, Z. Effects of combined aqueous chlorine dioxide and chitosan coatings on microbial growth and quality maintenance of fresh-cut bamboo shoots (Phyllostachys praecox f. prevernalis.) during storage. Food Bioprocess Technol. 2015, 8, 1011-1019. [CrossRef] 